\title{
Hubungan perilaku pencarian informasi guru militer dengan hasil pembelajaran pembekalan angkutan TNI AD Cimahi
}

\author{
Sita Purnama ${ }^{1}$, Pawit M. Yusup ${ }^{2}$, Nuning Kurniasih ${ }^{3}$ \\ 1,2,3Program Studi Ilmu Perpustakaan Universitas Padjadjaran \\ Jl. Raya Bandung-Sumedang Km.21, Jatinangor, Sumedang, Jawa Barat 45363 \\ E-mail: 1sitapurnama22111994@gmail.com, 2pawitmy@gmail.com, ${ }^{3}$ nuningkurniasih@yahoo.com
}

Received: Juni 2016; Accepted: Mei 2018; Published: May 2018

\begin{abstract}
Information needs are necessary for humans to answer questions that are in the mind, in order to enhance their professions or main activities. The needs of each person are influenced by different situations, cognitions and physiological backgrounds. All aspects of human life require information which is expected to continuously support the improvement of life patterns toward increasing complexities. The purpose of this study was to identify and analyze the relationship of information seeking behavior by military instructors with the learning outcomes of transportation briefing of the Indonesian Army in Cimahi. This study used the correlational research method with the Spearman rank statistical test; study results showed: 1) a positive relationship between the information seeking behavior of the initiation phase and learning outcomes of transportation briefing; 2) a positive relationship between the information seeking behavior of the selection phase and the learning outcomes of transportation briefing; 3) a positive relationship between the information retrieval behavior of the exploration stage and the learning outcomes of transportation briefing; 4) a positive relationship between the information seeking behavior of the formulation stage and the learning outcomes of transportation briefing; 5) a positive relationship between the information collection stage collection behavior and the learning outcomes of transportation briefing; and 6) a positive relationship between the information seeking behavior of the presentation stage and the learning outcomes of transportation briefing. In conclusion, there is a positive relationship between information seeking behavior by military instructors and the learning outcomes of transportation briefing.
\end{abstract}

Keywords: Information seeking behavior; Learning outcomes; Military instructors

\begin{abstract}
Abstrak
Kebutuhan akan informasi dapat dikatakan sebagai apa yang sedang dibutuhkan oleh manusia untuk dapat menjawab pertanyaan yang berada di benaknya demi menunjang profesi ataupun kegiatan utama manusia tersebut. Kebutuhan dari tiap orang dipengaruhi oleh latar belakang situasi, kognisi dan juga fisiologis berbeda. Seluruh aspek kehidupan manusia membutuhkan informasi yang diharapkan dapat menunjang peningkatan pola kehidupan yang terus menerus menuju kompleksitas yang semakin tinggi. Tujuan dari penelitian ini untuk mengetahui dan menganalisis hubungan perilaku pencarian informasi oleh guru militer dengan hasil pembelajaran pembekalan angkutan Tentara Nasional Indonesia Angkatan Darat (TNI AD) Cimahi. Peneliti menggunakan metode penelitian korelasional dengan uji statistik Spearman's rank, hasil penelitian menjelaskan bahwa: 1) Ada hubungan positif antara perilaku pencarian informasi tahap inisiasi dengan hasil pembelajaran pembekalan angkutan; 2) Ada hubungan positif antara perilaku pencarian informasi tahap seleksi dengan hasil pembelajaran pembekalan angkutan; 3) Ada hubungan positif antara perilaku pencarian informasi tahap eksplorasi dengan hasil pembelajaran pembekalan angkutan; 4) Ada hubungan positif antara perilaku pencarian informasi tahap formulasi dengan hasil pembelajaran pembekalan angkutan; 5) Ada hubungan positif antara perilaku pencarian informasi tahap koleksi dengan hasil pembelajaran pembekalan angkutan; 6) Ada hubungan positif antara perilaku pencarian informasi tahap presentasi dengan hasil
\end{abstract}


pembelajaran pembekalan angkutan. Kesimpulannya adalah terdapat hubungan positif antara perilaku pencarian informasi oleh guru militer dengan hasil pembelajaran pembekalan angkutan.

Kata Kunci: Perilaku pencarian informasi; Hasil pembelajaran; Guru militer

\section{PENDAHULUAN}

Gelinas and Dull

mendefinisikan informasi sebagai data yang disajikan dalam suatu bentuk yang berguna terhadap aktifitas pengambilan keputusan. Romney and Steinbart (2015) menjelaskan informasi merupakan data yang telah dikelola dan di proses untuk memberikan arti dan memperbaiki proses pengambilan keputusan.

Kebutuhan informasi dapat dikatakan sebagai apa yang sedang dibutuhkan oleh manusia untuk menjawab pertanyaan yang berada di benaknya demi menunjang profesi ataupun kegiatan utama manusia tersebut. Kebutuhan dari tiap orang dipengaruhi latar belakang situasi, kognisi dan fisiologis berbeda.

Seluruh aspek kehidupan manusia membutuhkan informasi yang diharapkan dapat menunjang peningkatan pola kehidupan yang terus menerus menuju kompleksitas yang semakin tinggi. Intinya, informasi memberikan kemudahan manusia dalam melakukan aktivitasnya di berbagai bidang (Gumilar, 2016)

Menurut Gelinas and Dull (2012), terdapat beberapa karakteristik informasi yang berkualitas, yaitu: (a) effectiveness: berkaitan dengan informasi yang relevan dan berkaitan dengan proses bisnis yang di sampaikan dengan tepat waktu, benar, konsisten dan dapat digunakan, (b) efficiency: informasi yang berkaitan melalui penyediaan informasi secara optimal terhadap penggunaan sumber daya, (c) confidentiality: karakteristik informasi yang berkaitan dengan keakuratan dan kelengkapan informasi serta validitas nya sesuai dengan nilai-nilai bisnis dan harapan, (d) integrity: karakteristik informasi yang berkaitan dengan perlindungan terhadap informasi yang sensitif dari pengungkapan yang tidak sah, (e) availability: suatu karakteristik informasi yang berkaitan dengan informasi yang tersedia pada saat diperlukan oleh proses bisnis baik sekarang, maupun di masa mendatang, hal ini juga menyangkut perlindungan sumber daya yang diperlukan dan kemampuan yang terkait, (f) compliance: yaitu karakteristik informasi yang berkaitan dengan mematuhi peraturan dan perjanjian kontrak dimana proses bisnis merupakan subjeknya berupa kriteria bisnis secara internal maupun eksternal, (g) reliability: karakteristik informasi yang berkaitan dengan penyediaan informasi yang tepat bagi manajemen untuk mengoperasikan entitas dan menjalankan tanggung jawab serta tata kelola pemerintahan.

$$
\text { Krikelas dalam Rosita (2006) }
$$
menyatakan bahwa perilaku pencarian informasi adalah kegiatan dalam menentukan dan mengidentifikasikan pesan untuk memuaskan kebutuhan informasi yang dirasakan. Selain itu, Luki dalam Rosita (2006) pun menjelaskan bahwa perilaku pencarian informasi merupakan aktivitas pemakai untuk mencari, mengumpulkan, dan memakai informasi yang mereka butuhkan.

Pada model perilaku pencarian informasi yang dikemukan oleh Wilson (1999) terdapat Intervening Variable sebagai 
faktor yang menentukan tingkat keberhasilan dalam memenuhi kebutuhan informasi. Wilson mengkategorikan yang termasuk sebagai Intervening Variable itu adalah personal (psikologis dan demografis), role-related (aturan yang berperan) atau interpersonal, environmental (lingkungan), dan karakteristik sumber informasi.

\section{Menurut Sulistyo-Basuki} kebutuhan informasi adalah informasi yang diinginkan seseorang untuk pekerjaan, penelitian, kepuasan rohaniah, pendidikan dan lain-lain. Dapat disimpulkan bahwa kebutuhan informasi merupakan keinginan seseorang dalam memperoleh pengetahuan yang bernilai guna untuk dirinya.

Informasi dibutuhkan untuk peningkatan pengetahuan, pengambilan keputusan dan sarana hiburan. Hal ini juga dilakukan oleh seorang guru militer, dimana mereka membutuhkan informasi untuk menambah wawasan dan untuk peningkatan kualitas pembelajaran. Meskipun seorang guru militer telah mengikuti proses pendidikan yang dilakukan tidak hanya dalam satu pusat pendidikan saja, tetapi lebih dari tiga pusat pendidikan, mereka tetap membutuhkan informasi dalam menjalankan tugasnya.

Sumber informasi bisa didapatkan dari mana saja, baik itu sumber informasi yang berada di dalam instansi pendidikan atau pemerintahan, atau dari luar instansi. Sumber informasi yang digunakan haruslahsumber informasi yang bisa dipercaya dan bisa dipertanggung jawabkan. Hal ini dikarenakan menjadi seorang anggota militer bukan hanya dituntut untuk cepat, tegas dan bertanggung jawab, akan tetapi, mereka juga harus pintar dalam segala bidang baik itu bahasa, kesehatan dan teknologi.

Anggota militer dituntut untuk memiliki kemampuan memilih dan memilah sumber informasi yang layak disajikan. Sumber informasi tersebut harus bisa dipahami oleh banyak orang. Hal ini dilakukan agar jika terdapat penyalahgunaan dan penyimpangan atas informasi yang tidak sesuai dengan norma dan jati diri bangsa dapat dicegah sebaik mungkin karena hal tersebut dapat berimplikasi terhadap ketahanan nasional dan menggoyahkan sendi-sendi kehidupan berbangsa dan bernegara di wilayah Negara Kesatuan Republik Indonesia (NKRI).

Akan sangat ditakutkan ketidakmampuan anggota militer, dalam hal ini guru militer, untuk menghadapi era teknologi informasi yang sangat pesat dapat menjadi ancaman apabila suatu bangsa dan negara tidak memiliki kapasitas atau kemampuan untuk menentukan sumber informasi yang tepat dan memanfaatkan teknologi informasi secara baik, benar, dan tepat guna khususnya di Pusat Pendidikan Militer.

Guru militer bertugas salah satunya di Pusat Pendidikan Pembekalan Angkutan (PUSDIK BEKANG). PUSDIK BEKANG ini merupakan salah satu pusat pendidikan militer dalam bidang pembekalan angkutan. Pusat pendidikan ini diresmikan melalui upacara peresmian di Cimahi pada tanggal 14 Januari 1986.Banyak sekali perubahan nama yang dilakukan pada pusat pendidikan ini. Tetapi, semenjak tahun 1986 Lembaga Pendidikan Pembekalan Dan Angkutan berubah namanya menjadi Pusat Pendidikan Pembekalan Angkutan (PUSDIK BEKANG) sampai dengan saat ini. 
Pembekalan dalam hal ini dibagi menjadi empat kelas. Pertama mengenai makanan, yang kedua angkutan, ketiga perminyakan, dan yang terakhir yaitu alat-alat kantor seperti kursi, meja dan lemari. Sementara itu, angkutan dalam hal ini adalah segala sesuatu yang berhubungan dengan tranportasi yang ada di angkatan darat, laut dan udara.

Guru militer atau disebut juga dengan Instruktur militer mengajar para anggota militer yang mengikuti pendidikan di Pusat Pendidikan Militer khususnya di PUSDIKBEKANG. Guru militer biasanya berpangkat Perwira, karena jika belum mencapai perwira, seorang anggota militer belum diperbolehkan untuk menjadi seorang guru militer. Materi yang biasa disampaikan dan yang paling utama adalah tentang peraturan penghormatan militer, angkutan, perlengkapan perorangan lapangan (kaporlap), perminyakan, olahraga Youngmoodo dan makanan.

Ketika guru militer membutuhkan informasi untuk menambah wawasan mereka. Guru militer melakukan pencarian informasi dengan melakukan analisis terlebih dahulu terhadap informasi yang mereka butuhkan, setelah itu mereka mulai memilih apa saja yang benar-benar mereka butuhkan, setelah memilih informasi mereka mulai mencari informasi dengan cara mencari dari negara mana atau instansi apa informasi yang mereka butuhkan sehingga mereka fokuskan pencarian mereka terhadap satu fokus pencarian saja. Setelah proses pencarian informasi mereka merumuskan dari beberapa sumber yang mereka cari lalu mereka mengumpulkan dan menarik kesimpulan dari informasi yang mereka cari serta mulai mempresentasikannya kepada peserta didik yang melakukan pendidikan di PUSDIKBEKANG tersebut.

Berdasarkan uraian yang telah dipaparkan, maka permasalahan yang akan diteliti dapat diidentifikasi sebagai berikut: (1) Sejauhmana hubungan antara pencarian informasi tahap inisiasi (awal pencarian informasi) dengan hasil pembelajaran? (2) Sejauhmana hubungan antara pencarian informasi tahap seleksi (pemilihan informasi) dengan hasil pembelajaran? (3) Sejauhmana hubungan antara pencarian informasi tahap eksplorasi (penelusuran informasi) dengan hasil pembelajaran? (4) Sejauhmana hubungan antara pencarian informasi tahap formulasi (perumusan informasi) dengan hasil pembelajaran? Sejauhmana hubungan antara pencarian informasi tahap koleksi (pengumpulan informasi) dengan hasil pembelajaran? (6) Sejauhmana hubungan antara pencarian informasi tahap presentasi (penyajian informasi) dengan hasil pembelajaran?

Adapun tujuan dari penelitian ini yaitu: (1) Untuk mengetahui sejauhmana hubungan antara pencarian informasi tahap inisiasi (awal pencarian informasi) dengan hasil pembelajaran. (2) Untuk mengetahui sejauhmana hubungan antara pencarian informasi tahap seleksi (pemilihan informasi) dengan hasil pembelajaran. (3) Untuk mengetahui sejauhmana hubungan antara pencarian informasi tahap eksplorasi (penelusuran informasi) dengan hasil pembelajaran. (4) Untuk mengetahui sejauhmana hubungan antara pencarian informasi tahap formulasi (perumusan informasi) dengan hasil pembelajaran. (5) Untuk mengetahui sejauhmana hubungan antara pencarian informasi tahap koleksi (pengumpulan informasi) dengan hasil pembelajaran. (6) Untuk mengetahui sejauhmana hubungan 
antara pencarian informasi tahap presentasi (penyajian informasi) dengan hasil pembelajaran.

\section{METODE PENELITIAN}

Metode yang digunakan dalam penelitian ini menggunakan metode penelitian kuantitatif dengan pendekatan korelasional. Menurut Sugiyono (2015), metode penelitian kuantitatif merupakan metode penelitian yang berlandaskan pada filsafat positivisme, digunakan untuk meneliti pada populasi atau sampel tertentu, teknik pengambilan sampel pada umumnya dilakukan secara random, pengumpulan data menggunakan instrumen penelitian, analisis data bersifat kuantitatif atau statistik dengan tujuan untuk menguji hipotesis yang telah ditetapkan.

Cara ilmiah berarti kegiatan penelitian itu didasarkan pada ciri-ciri keilmuan, yaitu rasional, empiris dan sistematis. Rasional berarti kegiatanpenelitian itu dilakukan dengan cara-cara yang masuk akal, sehingga terjangkau oleh penalaran manusia. Empiris berarti cara-cara yang dilakukan itu dapat diamati oleh indera manusia, sehingga orang lain dapat mengamati dan mengetahui cara-cara yang digunakan. Sistematis artinya, proses yang digunakan dalam penelitian itu menggunakan langkah-langkah tertentu yang bersifat logis (Sugiyono, 2015).

Metode kuantitatif yang digunakan, dilengkapi dengan model penelitian korelasional. Penelitian korelasi atau korelasional adalah suatu penelitian untuk mengetahui hubungan dan tingkat hubungan antara dua variabel atau lebih tanpa ada upaya untuk mempengaruhi variabel tersebut sehingga tidak terdapat manipulasi variabel (Faenkel \& Wallen, 2008).

Metode korelasi bertujuan meneliti sejauh mana variasi pada satu faktor berkaitan dengan variasi pada faktor lain. Jika terdapat dua variabel yang berhubungan, korelasinya disebut korelasi sederhana (simple correlation). Jika variabelnya lebih dari dua, kita menggunakan korelasi ganda (multiple correlation).

Menurut Rakhmat (2009), metode korelasional digunakan untuk : (1) Mengukur hubungan diantara berbagai variabel. (2) Meramalkan variabel tak bebas dari pengetahuan kita tentang variabel bebas. (3) Meratakan jalan untuk membuat rancangan penelitian eksperimental.

Dalam penelitian ini populasinya yaitu semua guru militer yang ada di PUSDIK BEKANG Tentara Nasional Indonesia Angkatan Darat (TNI AD) Cimahi, yaitu sebanyak 134 guru militer. Kemudian, melalui penggunaan teknik probability sampling, responden yang dibutuhkan dalam penelitian ini adalah 101 orang. Teknik sampling yang digunakan dalam penelitian ini adalah sampling acak sederhana, karena pengambilan sampel anggota populasi dilakukan secara acak tanpa memperhatikan strata yang ada dalam populasi tersebut.

Penelitian ini menggunakan metode korelasi Spearman's rank. Korelasi Spearman's rank dimaksud untuk mencari indeks korelasi antara dua variabel yang menggunakan skala ordinal sehingga objek atau dua variabel yang menggunakan skala ordinal sehingga objek-objek atau individu yang dipelajari dapat ranking dalam dua rangkaian berurutan (Siegel, 1992). 
Populasi dan sampel yang diolah dengan menggunakan metode korelasi Spearman's rank tersebut merupakan data pokok dimana analisisnya ditunjang oleh data-data sekunder yang didapat dari hasil observasi di lapangan dan beberapa sumber pustaka serta wawancara untuk memperkuat dan memperdalam hasil analisis. Data penelitian tersebut diolah dan kemudian dilakukan pembahasan.

\section{HASIL DAN PEMBAHASAN}

Kebutuhan informasi dalam setiap individu berbeda. Hal ini dikarenakan masing-masing individu memiliki tingkatan kebutuhan yang berbeda-beda. Untuk memenuhi kebutuhan akan informasi, kita harus memulainya dengan kegiatan pencarian informasi.

Berikut hasil perhitungan untuk setiap sub variabel dan variabel dalam penelitian:

Tabel 1

Perilaku guru militer pada tahap inisiasi (awal pencarian informasi)

\begin{tabular}{llll}
\hline No & $\begin{array}{l}\text { Perilaku guru militer pada } \\
\text { tahap inisiasi (awal } \\
\text { pencarian informasi) }\end{array}$ & F & \% \\
\hline 1 & Tinggi & 82 & 81.2 \\
2 & Sedang & 13 & 12.9 \\
3 & Rendah & 6 & 5.9 \\
Jumlah & 101 & 100 \\
\hline
\end{tabular}

Sumber: Pengolahan data 2017

Berdasarkan tabel 1, jawaban responden pada item-item mengenai perilaku guru militer pada tahap inisiasi (awal pencarian informasi) yaitu 85 dalam kategori tinggi sebanyak 82 orang $(81.2 \%)$, kategori sedang 13 orang (12.9\%), dan kategori rendah 6 orang (5.9\%). Dengan demikian, responden cenderung menjawab perilaku guru militer pada tahap inisiasi (awal pencarian informasi) dalam kategori tinggi. Kenapa tahap awal ini termasuk kategori tinggi karena seorang guru militer tidak sembarang memilih informasi, mereka harus menganalisis terlebih dahulu apa yang mereka butuhkan lalu terdapat poin apa saja yang terdapat didalamnya dan apa saja yang sekiranya bersangkutan dengan informasi yang mereka butuhkan.

Tabel 2

Perilaku guru militer pada tahap seleksi (pemilihan informasi)

\begin{tabular}{llll}
\hline No & $\begin{array}{l}\text { Perilaku guru militer } \\
\text { pada tahap seleksi } \\
\text { (pemilihan informasi) }\end{array}$ & F & \% \\
\hline 1 & Tinggi & 79 & 78.2 \\
2 & Sedang & 18 & 17.8 \\
3 & Rendah & 4 & 4.0 \\
Jumlah & 101 & 100 \\
\hline
\end{tabular}

Sumber: Pengolahan data 2017

Berdasarkan tabel 2, jawaban responden pada item-item mengenai perilaku guru militer pada tahap seleksi (pemilihan informasi) yaitu dalam kategori tinggi sebanyak 79 orang (78.2\%), kategori sedang 18 orang 86 (17.8\%), dan kategori rendah 4 orang $(4.0 \%)$. Dengan demikian, responden cenderung menjawab perilaku guru militer pada tahap seleksi (pemilihan informasi) dalam kategori tinggi. Kenapa bisa termasuk kategori tinggi karena seorang guru militer harus lebih teliti dalam memilih dan memilah informasi dan sumber informasi yang mereka butuhkan. Apakah sumber informasi itu sudah relevan dan bisa di pertanggung jawabkan apa belum. 
Tabel 3

Perilaku guru militer pada tahap eksplorasi (penelusuran informasi)

\begin{tabular}{llll}
\hline No & $\begin{array}{l}\text { Perilaku guru militer } \\
\text { pada tahap eksplorasi } \\
\text { penelusuran informasi) }\end{array}$ & F & \% \\
\hline 1 & Tinggi & 63 & 62.4 \\
2 & Sedang & 32 & 31.7 \\
3 & Rendah & 6 & 5.9 \\
Jumlah & 101 & 100 \\
\hline
\end{tabular}

Sumber: Pengolahan data 2017

Berdasarkan tabel 3, jawaban responden pada item-item mengenai perilaku guru militer pada tahap eksplorasi (penelusuran informasi) yaitu dalam kategori tinggi sebanyak 63 orang (62.4\%), kategori sedang 32 orang (31.7\%), dan kategori rendah 6 orang (5.9\%). Dengan demikian, responden cenderung menjawab perilaku guru militer pada tahap eksplorasi (penelusuran 87 informasi) dalam kategori tinggi. Karena setiap orang membutuhkan informasi baik itu untuk dirinya sendiri ataupun buat orang lain. Tapi disini seorang guru militer mencari informasi melalui web secara online dikarenakan melihat kesibukann yang dilakukan oleh seorang anggota militer itu untuk pergi ke perpustakaan.

Tabel 4

Perilaku guru militer pada tahap formulasi (perumusan informasi)

\begin{tabular}{llll}
\hline No & $\begin{array}{l}\text { Perilaku guru militer } \\
\text { pada tahap formulasi } \\
\text { (perumusan informasi) }\end{array}$ & F & \% \\
\hline 1 & Tinggi & 77 & 76.2 \\
2 & Sedang & 20 & 19.8 \\
3 & Rendah & 4 & 4.0 \\
Jumlah & 101 & 100 \\
\hline
\end{tabular}

Sumber: Pengolahan data 2017

Berdasarkan tabel 4, jawaban responden pada item-item mengenai perilaku guru militer pada tahap formulasi (perumusan informasi) yaitu dalam kategori tinggi sebanyak 77 orang $(76.2 \%)$, kategori sedang 20 orang (19.8\%), dan kategori rendah 4 orang $(4.0 \%)$. Dengan demikian, responden cenderung menjawab perilaku guru militer pada tahap formulasi (perumusan informasi) dalam kategori tinggi. Setiap orang setelah memiliki informasi yang telah didapat itu tidak bisa langsung mendapatkan informasi yang sudah sesuai tetapi harus melalui beberapa tahap dulu seperti perumusan, pengklasifikasikan informasi tersebut dan mengecek apakah informasi tersebut relevan atau tidak.

Tabel 5

Perilaku guru militer pada tahap koleksi

(pengumpulan informasi)

\begin{tabular}{llll}
\hline No & $\begin{array}{l}\text { Perilaku guru militer } \\
\text { pada tahap koleksi } \\
\text { (pengumpulan } \\
\text { informasi) }\end{array}$ & F & $\%$ \\
\hline 1 & Tinggi & 64 & 63.4 \\
2 & Sedang & 34 & 33.7 \\
3 & Rendah & 3 & 3.0 \\
Jumlah & 101 & 100 \\
\hline
\end{tabular}

Sumber: Pengolahan data 2017

Berdasarkan tabel 5, jawaban responden pada item-item mengenai perilaku guru militer pada tahap koleksi (pengumpulan informasi) yaitu dalam kategori tinggi sebanyak 64 orang $(63.4 \%)$, kategori sedang 34 orang (33.7\%), dan kategori rendah 3 orang $(3.0 \%)$. Dengan demikian, responden cenderung menjawab perilaku guru militer pada tahap koleksi (pengumpulan informasi) dalam kategori tinggi. Karena guru militer harus memeriksa dan memeriksa lagi informasi yang telah didapat karena didalam militer itu perlu ketelitian yang sangat tinggi jadi seorang guru militer tidak langsung memasukan infomasi yang didapat kedalam dasar penulisan mereka.

Hubungan perilaku pencarian informasi guru militer dengan hasil pembelajaran pembekalan angkutan TNI AD 
Tabel 6

Perilaku guru militer pada tahap presentasi (penyajian informasi)

\begin{tabular}{llll}
\hline No & $\begin{array}{l}\text { Perilaku guru militer } \\
\text { pada tahap presentasi } \\
\text { (penyajian informasi) }\end{array}$ & F & $\%$ \\
\hline 1 & Tinggi & 76 & 75.2 \\
2 & Sedang & 24 & 23.8 \\
3 & Rendah & 1 & 1.0 \\
Jumlah & 101 & 100
\end{tabular}

Sumber: Pengolahan data 2017

Berdasarkan tabel 6, jawaban responden pada item-item mengenai perilaku guru militer pada tahap presentasi (penyajian informasi) yaitu dalam kategori tinggi sebanyak 76 orang $(75.2 \%)$, kategori sedang 24 orang $(23.8 \%)$, dan kategori rendah 1 orang $(1.0 \%)$ Dengan demikian, responden cenderung menjawab perilaku guru militer pada tahap presentasi (penyajian informasi) dalam kategori tinggi. Tahap presentasi memang ada bisa dikatakan guru itu ada tahap transfer informasi dari seorang komunikan kepada komunikator jadi guru memberikan ilmu yang telah mereka dapat kepada peserta didik.

Tabel 7

Perilaku pencarian informasi

\begin{tabular}{llll}
\hline No & $\begin{array}{l}\text { Perilaku pencarian } \\
\text { informasi }\end{array}$ & F & \% \\
\hline 1 & Tinggi & 59 & 58.4 \\
2 & Sedang & 31 & 30.7 \\
3 & Rendah & 11 & 10.9 \\
Jumlah & 101 & 100
\end{tabular}

Sumber: Pengolahan data 2017

Berdasarkan tabel 7, jawaban responden pada item-item mengenai perilaku pencarian informasi yaitu dalam kategori tinggi sebanyak 59 orang (58.4\%), kategori sedang 31 orang $(30.7 \%)$, dan kategori rendah 11 orang (10.9\%). Dengan demikian, responden cenderung menjawab perilaku pencarian informasi dalam kategori tinggi. Karena setiap guru militer wajib membuat yang namanya paket instruksi jadi pencarian informasi selalu harus diadakan hampir setiap harinya. Karena setiap hari selalu ada tahap interaksi dengan peserta didik baik itu pendidikan didalam kelas maupun diluar kelas. Karena pendidikan diluar dan didalam kelas semuanya hampir seimbang.

Tabel 8

Hasil pembelajaran

\begin{tabular}{llll}
\hline No & Hasil pembelajaran & F & \% \\
\hline 1 & Tinggi & 88 & 87.1 \\
2 & Sedang & 12 & 11.9 \\
3 & Rendah & 1 & 1.0 \\
Jumlah & 101 & 100
\end{tabular}

Sumber: Pengolahan data 2017

Berdasarkan tabel 8, jawaban responden pada item-item tentang hasil pembelajaran yaitu dalam kategori tinggi sebanyak 88 orang (87.1\%), kategori sedang 12 orang $(11.9 \%)$, dan kategori rendah 1 orang $(1.0 \%)$. Dengan demikian, responden cenderung menjawab hasil pembelajaran dalam kategori tinggi. Kenapa hasil belajar bisa dikatakan berkategori tinggi karena setiap pendidikan memiliki tahap akhir pendidikan yaitu hasil bagaimana dengan apa yang sudah mereka lakukan selama mengikuti pendidikan tersebut

Dalam mencari informasi yang dibutuhkan oleh para guru militer selalu memiliki motivasi karena bisa kita ketahui bahwa setiap orang membutuhkan informasi didasarkan atas apa yang membuat mereka termotivasi untuk mencari informasi tersebut.

Motivasi berasal dari kata motif, menurut Sudirman (2007) motif yang diartikan sebagai penggerak yang mendorong seseorang melakukan 
aktivitas-aktivitas tertentu untuk mencapai satu tujuan. Motif yang sudah aktif disebut motivasi, sedangkan menurut Berelson dan Stener dalam Sofiah (2003) mendifinisikan motiv sebagai suatu keadaan di dalam diri seseorang yang mendorong, mengaktifkan atau menggerakkan, dan mengarahkan perilaku pada tujuan.

Alasan mengapa motivasi masuk ke dalam tahap awal pencarian informasi karena motivasi merupakan salah satu aspek yang termasuk kedalam perilaku.

Pencarian informasi merupakan tindakan awal dalam memenuhi kebutuhan informasi. Ketika seseorang membutukan informasi, maka mereka dengan sendirinya akan mencari informasi. Apalagi hal ini didasari oleh adanya kebutuhan yang wajib. Seorang guru militer setiap 3 sampai 4 kali dalam 1 tahun wajib memperbaiki paket intruksi sehingga guru militer selalu memikirkan apa yang harus ditambahkan kedalam paket intruksi tersebut. Mencari informasi itu hal wajib ketika kita membutuhkan informasi. Informasi yang kita butuhkan tidak datang dengan sendirinya tetapi kita harus mencarinya dengan melalui sumber-sumber informasi yang relevan.

Para guru militer pun memulainya dengan menentukan topik awal adalah dasar untuk melakukan pencarian informasi. Setiap kali para guru militer akan mencari informasi, meraka harus menentukan topik apa yang mereka butuhkan agar mereka tidak bingung dengan apa yang akan mereka cari ketika proses pencarian informasi.

Pada dunia militer banyak sekali yang harus dipelajari tidak hanya dalam bidang militer saja tetapi dalam bidang informasi dan komunikasi sehingga setiap guru militer harus menetukan topik utama tentang informasi apa yang benar-benar mereka butuhkan.

Dalam melakukan analisis terhadap topik yang sudah ditentukan itu sangat wajib dilakukan oleh para guru militer. Tindakan analisis topik memang harus diadakan ketika mereka akan mencari informasi seperti hal apa saja yang ada dalam topik yang para guru militer itu butuhkan.

Seperti halnya dengan guru militer, mereka cenderung menganalisis dari negara mana topik yang mereka butuhkan. Contohnya, ketika mencari informasi mengenai bela diri Youngmoodo, mereka harus menganalisis asal mula adanya bela diri Youngmoodo, bagaimana trik agar dapat melakukan bela diri tersebut dengan baik, dan lain sebagainya.

Saat ini, banyak sumber informasi yang akan memberikan informasi, akan tetapi kita harus mengetahuikategori sumber informasi yang relevan. Maka daripada itu, tindakan dalam memilih sumber informasi yang digunakan mereka lakukan dengan baik. Hampir semua guru militer melakukan pencarian infomasi melalui media online tetapi terlalu banyak sumber-sumber yang memberikan informasi yang tidak relevan, maka dari itu guru militer sangat teliti dalam menentukan sumber informasi.

Setelah menentukan sumber informasi, kegiatan yang selanjutnya dilakukan oleh guru militer adalah menetapkan sumber informasi, dimana tindakan mengambil keputusan sumber informasi ini adalah kegiatan dimana para guru militer menetapkan informasi apa yang akan digunakan. Hal ini sangat perlu agar mereka tidak bingung dalam mencari informasi yang mereka butuhkan. Menetapkan sumber informasi yang tepat itu biasa dilakukan oleh guru militer agar 
mereka tidak bingung lagi dengan informasi yang akan mereka butuhkan.

Banyak hal yang bisa dilakukan ketika seorang guru militer membutuhkan informasi, salah satunya melalui situs web yang mereka anggap itu adalah sumber yang relevan. Kegiatan mengakses informasi melalui web tersebut dipilih oleh para guru militer karena hal tersebut dapat dilakukan oleh guru militer ditengah kegiatan mereka yang sangat padat.

Dalam mengambil tindakan untuk mendapatkan informasi secara online, para guru militer menyatakan kesetujuannya. Dilihat dari tingkat kesibukan yang dilakukan oleh seorang guru militer, sangat sedikit waktu untuk mereka mencari informasi melalui perpustakaan. Meskipun pihak instansi sudah menyediakan sebuah perpustakaan tetapi setelah melihat kesibukan anggota militer itu tidak memungkinkan untuk pergi keperpustakaan jadi seorang guru militer rata-rata mencari informasi melalui situs online.

Begitu pun dalam membuka halaman yang ditampilkan, ketika guru militer melakukan pencarian informasi melalui situs web, dengan otomatis mereka harus membuka halaman per halaman, apakah informasi yang dibutuhkan telah sesuai dengan apa yang gurumiiter butuhkan atau belum karena kebanyakan informasi yang ada itu masih banyak yang kurang sesuai dengan apa yang dibutuhkan.

Setelah para guru militer membuka salah satu situs web, mereka akan mengembangkan linkweb tersebut. Hal ini dilakukan karena para guru militer yang membutuhkan informasi tersebut akan terus dan terus mengembangkan link tersebut sampai informasi yang dicari telah sesuai dengan apa yang guru militer butuhkan.

Rangkaian pencarian informasi selesai dalam tahap mengunduh informasi. Hal ini dilakukan karena setelah infomasi yang dibutuhkan telah sesuai, maka akan ada proses pengunduhan dengan informasi yang telah didapat. Karena disini semua guru militer melakukan pencarian informasi melalui situs online maka akan ada tahap dimana informasi itu diunduh agar informasi yang guru militer butuhkan tidak berubah-ubah.

Langkah selanjutnya adalah melakukan tindakan dalam melakukan proses perumusan informasi. Proses perumusan informasi ini perlu dilakukan setelah proses pengunduhan informas agar informasi yang telah didapat lebih mudah di rumuskan. Hasil wawancara dengan salah satu guru militer, bahwa informasi yang guru militer dapatkan tidak langsung membuat kesimpulan karena mereka rasa informasi yang telah diunduh wajib melalui tahapan perumusan.

Dari infomasi yang telah didapat maka harus di pilih kembali karena tidak semua informasi yang didapat itu relevan dalam tahap ini guru militer mensortir kembali informasi yang telah mereka dapatkan karena tidak semua informasi yang telah didapat termasuk kedalam topik awal yang mereka cari.

Untuk membaca informasi yang didapat sangat perlu, karena tidak semua informasi yang didapat telah sesuai makan kita harus terus mengecek informasi yang telah didapat. Guru militer tidak hanya di dalam lapangan saja yang memerlukan ketelitian tetapi dalam informasi yang sudah mereka dapatkan pun selalu dibaca dan dicek kembali untuk memastiakn 
bahwa informasi yang sudah didapat telah sesuai dengan apa yang mereka butuhkan.

Setelah informasi tersebut dibaca, maka selanjutnya adalah teknik dalam pengumpulan informasi, dimana setiap orang memiliki cara dalam mengumpulkan dan memilih informasi yang telah didapat, salah satu cara yang guru militer yaitu memilih dan melilah informasi yang mereka telah dapat setelah proses pengunduhan sebulumnya.

Dari topik yang telah ditentukan, lalu informasi telah didapat makan setiap topik yang telah diapat mulai di klasifikasikan sesuai dengan analisis topik sebelumnya kenapa guru militer melakukan ini karena untuk memudakan dalam membuat kesimpulan akhir jadi harus melalukan pengklasifikasian terlebih dahulu.

Setelah informasi yang didapat telah selesai diterjemahkan, maka hal yang harus dilakukan selanjutnya adalah membuat kesimpulan sementara. Hal ini diperoleh dari hasil pengklasfikasian informasi yang kemudian didapat kesimpulan sementara dari informasi yang dibutuhkan mengapa begitu itu dilakukan untuk lebih mempersempit lagi informasi yang didapat agar nanti informasi yang diambil benar-benar informasi yang sesuai dengan yang mereka butuhkan.

Kesimpulan sementara ini akan diolah kembali yang dituangkan dalam bentuk parafrase yang lain. Hal ini dikarenakan dalam membuat kesimpulan itu biasanya dilakukan ketika informasi yang telah didapat sudah sesuai dengan apa yang diperlukan seorang guru militer.

Informasi yang didapat dari hasil kesimpulan tersebut digunakan untuk menambah kutipan bahan ajar. Bahan ajar memang harus dimiliki oleh setiap guru militer karena itu adalah hal wajib dipegang oleh guru militer ketika mengajar dikelas.

Para guru militer menyajikan informasi yang telah diolah kedalam bentuk paket intruksi dimana dalam menyajiakan sebuah tulisan disini yaitu dalam bentuk paket intruksi yang harus dimiliki oleh guru militer. Paket Instruksi (PI) merupakan salah satu komponen yang menjadi ujung tombak keberhasilan dalam kegiatan proses belajar mengajar dalam dunia militer.

Seorang guru militer tidak boleh sembarang memilih informasi, mereka harus menganalisis terlebih dahulu apa yang mereka butuhkan lalu terdapat poin apa saja yang terdapat didalamnya dan apa saja yang sekiranya bersangkutan dengan informasi yang mereka butuhkan.

Guru militer harus lebih teliti dalam memilih dan memilah informasi dan sumber informasi yang mereka butuhkan. Apakah sumber informasi itu sudah relevan dan bisa di pertanggung jawabkan apa belum.

Untuk mengetahui hubungan antara perilaku pencarian informasi dengan hasil pembelajaran, peneliti menggunakan analisis data dengan koefisien korelasi Spearman's rank $\left(\mathrm{r}_{\mathrm{s}}\right)$. Hasil perhitungan dapat dilihat pada tabel berikut.

Tabel 9

Hubungan antara perilaku pencarian informasi dengan hasil pembelajaran

\begin{tabular}{lllll}
\hline Variabel & $\mathbf{r}_{\mathbf{s}}$ & $\mathbf{t}_{\text {hitung }}$ & $\mathbf{t}_{\text {tabel }}$ & Keputusan \\
\hline $\begin{array}{l}\text { Perilaku } \\
\text { pencarian }\end{array}$ & & & & \\
$\begin{array}{l}\text { informasi } \\
\text { dengan hasil }\end{array}$ & 0.533 & 6.268 & 1.984 & Ho ditolak \\
pembelajaran & & & & \\
\hline
\end{tabular}

Sumber: Pengolahan data 2017

Berdasarkan tabel 9, dapat dilihat koefisien korelasi Spearman's rank $\left(\mathrm{r}_{\mathrm{s}}\right)$ adalah sebesar 0.533. Hasil uji signifikansi 
diperoleh nilai $t$ hitung sebesar 6.268 dan nilai $\mathrm{t}$ tabel dengan $\mathrm{a}=5 \%$ dan $\mathrm{dk}$ (derajat kebebasan) $=\mathrm{n}-2=99$ adalah sebesar 1.984 maka dapat dilihat bahwa t hitung (6.268) > $\mathrm{t}$ tabel (1.984) sehingga Ho ditolak. Dengan demikian dapat disimpulkan bahwa terdapat hubungan yang signifikan antara perilaku pencarian informasi dengan hasil pembelajaran. Koefisien korelasi sebesar 0.533 menunjukkan keeratan hubungan antara perilaku pencarian informasi dengan hasil pembelajaran merupakan hubungan yang cukup berarti.

Untuk mengetahui hubungan perilaku guru militer pada tahap inisiasi (awal pencarian informasi) dengan hasil pembelajaran, peneliti menggunakan analisis data dengan koefisien korelasi Spearman's rank $\left(\mathrm{r}_{\mathrm{s}}\right)$. Hasil perhitungan dapat dilihat pada tabel berikut.

\section{Tabel 10}

Hubungan perilaku guru militer pada tahap inisiasi (awal pencarian informasi) dengan hasil pembelajaran

\begin{tabular}{|c|c|c|c|c|}
\hline Variabel & $\mathbf{r}_{\mathrm{s}}$ & $\mathbf{t}_{\text {hitung }}$ & $\mathbf{t}_{\text {tabel }}$ & Keputusan \\
\hline $\begin{array}{l}\text { Perilaku guru } \\
\text { militer pada } \\
\text { tahap inisiasi } \\
\text { (awal } \\
\text { pencarian } \\
\text { informasi) } \\
\text { dengan hasil } \\
\text { pembelajaran }\end{array}$ & 0.215 & 2.191 & 1.984 & Ho ditolak \\
\hline
\end{tabular}

Sumber: Pengolahan data 2017

Berdasarkan tabel 10, dapat dilihat koefisien korelasi Spearman's rank $\left(\mathrm{r}_{\mathrm{s}}\right)$ adalah sebesar 0.215. Hasil uji signifikansi diperoleh nilai $t$ hitung sebesar 2.191 dan nilai $t$ tabel dengan $a=5 \%$ dan $d k$ (derajat kebebasan) $=\mathrm{n}-2=99$ adalah sebesar 1.984 maka dapat dilihat bahwa t hitung (2.191) > $\mathrm{t}$ tabel (1.984) sehingga Ho ditolak. Dengan demikian dapat disimpulkan bahwa terdapat hubungan yang signifikan antara perilaku guru militer pada tahap inisiasi (awal pencarian informasi) dengan hasil pembelajaran. Koefisien korelasi sebesar 0.215 menunjukkan keeratan hubungan antara perilaku guru militer pada tahap inisiasi (awal pencarian informasi) dengan hasil pembelajaran merupakan hubungan rendah tapi pasti.

Untuk mengetahui hubungan perilaku guru militer pada tahap seleksi (pemilihan informasi) dengan hasil pembelajaran, peneliti menggunakan analisis data dengan koefisien korelasi Spearman's rank $\left(\mathrm{r}_{\mathrm{s}}\right)$. Hasil perhitungan dapat dilihat pada tabel berikut.

\section{Tabel 11}

Hubungan perilaku guru militer pada tahap seleksi (pemilihan informasi) dengan hasil pembelajaran

\begin{tabular}{|c|c|c|c|c|}
\hline Variabel & $\mathbf{r}_{\mathrm{s}}$ & $t_{\text {hitung }}$ & $t_{\text {tabel }}$ & Keputusan \\
\hline $\begin{array}{l}\text { Perilaku guru } \\
\text { militer pada } \\
\text { tahap seleksi } \\
\text { (pemilihan } \\
\text { informasi) } \\
\text { dengan hasil } \\
\text { pembelajaran }\end{array}$ & 0.412 & 4.496 & 1.984 & Ho ditolak \\
\hline
\end{tabular}

\section{Sumber: Pengolahan data 2017}

Berdasarkan tabel 11, dapat dilihat koefisien korelasi Spearman's rank $\left(\mathrm{r}_{\mathrm{s}}\right)$ adalah sebesar 0.412. Hasil uji signifikansi diperoleh nilai $\mathrm{t}$ hitung sebesar 4.496 dan nilai $\mathrm{t}$ tabel dengan $\mathrm{a}=5 \%$ dan dk (derajat kebebasan) $=\mathrm{n}-2=99$ adalah sebesar 1.984 maka dapat dilihat bahwa $t$ hitung (4.496) > $\mathrm{t}$ tabel (1.984) sehingga Ho ditolak. Dengan demikian dapat disimpulkan bahwa terdapat hubungan yang signifikan antara perilaku guru militer pada tahap seleksi (pemilihan informasi) dengan hasil pembelajaran. Koefisien korelasi sebesar 0.412 menunjukkan keeratan hubungan antara perilaku guru militer pada tahap seleksi 
(pemilihan informasi) dengan hasil pembelajaran merupakan hubungan yang cukup berarti.

Untuk mengetahui hubungan perilaku guru militer pada tahap eksplorasi (penelusuran informasi) dengan hasil pembelajaran, peneliti menggunakan analisis data dengan koefisien korelasi Spearman's rank $\left(\mathrm{r}_{\mathrm{s}}\right)$. Hasil perhitungan dapat dilihat pada tabel berikut.

\section{Tabel 12}

Hubungan perilaku guru militer pada tahap eksplorasi (penelusuran informasi) dengan hasil pembelajaran

\begin{tabular}{lcccc}
\hline Variabel & $\mathbf{r}_{\mathbf{s}}$ & $\mathbf{t}_{\text {hitung }}$ & $\mathbf{t}_{\text {tabel }}$ & Keputusan \\
\hline $\begin{array}{l}\text { Perilaku guru } \\
\text { militer pada } \\
\text { tahap }\end{array}$ & & & & \\
eksplorasi & & & & \\
(penelusuran & 0.4925 .629 & 1.984 & Ho ditolak \\
informasi) & & & \\
$\begin{array}{l}\text { dengan hasil } \\
\text { pembelajaran }\end{array}$ & & & & \\
\hline
\end{tabular}

Sumber: Pengolahan data 2017

Berdasarkan tabel 12, dapat dilihat koefisien korelasi Spearman's rank $\left(\mathrm{r}_{\mathrm{s}}\right)$ adalah sebesar 0.492. Hasil uji signifikansi diperoleh nilai $t$ hitung sebesar 5.629 dan nilai $t$ tabel dengan $\alpha=5 \%$ dan dk (derajat kebebasan) $=\mathrm{n}-2=99$ adalah sebesar 1.984 maka dapat dilihat bahwa t hitung (5.629) > $t$ tabel (1.984) sehingga Ho ditolak. Dengan demikian dapat disimpulkan bahwa terdapat hubungan yang signifikan antara perilaku guru militer pada tahap eksplorasi (penelusuran informasi) dengan hasil pembelajaran. Koefisien korelasi sebesar 0.492 menunjukkan keeratan hubungan antara perilaku guru militer pada tahap eksplorasi (penelusuran informasi) dengan hasil pembelajaran merupakan hubungan yang cukup berarti.

Untuk mengetahui hubungan perilaku guru militer pada tahap formulasi (perumusan informasi) dengan hasil pembelajaran, peneliti menggunakan analisis data dengan koefisien korelasi Spearman's rank $\left(\mathrm{r}_{\mathrm{s}}\right)$. Hasil perhitungan dapat dilihat pada tabel berikut.

Tabel 13

Hubungan perilaku guru militer pada tahap formulasi (perumusan informasi) dengan hasil pembelajaran

\begin{tabular}{|c|c|c|c|c|}
\hline Variabel & $\mathbf{r}_{\mathrm{s}}$ & $\mathbf{t}_{\text {hitung }}$ & $\mathbf{t}_{\text {tabel }}$ & Keputusan \\
\hline $\begin{array}{l}\text { Perilaku guru } \\
\text { militer pada } \\
\text { tahap } \\
\text { formulasi } \\
\text { (perumusan } \\
\text { informasi) } \\
\text { dengan hasil } \\
\text { pembelajaran }\end{array}$ & 0.495 & 5.668 & 1.984 & Ho ditolak \\
\hline
\end{tabular}

Sumber: Pengolahan data 2017

Berdasarkan tabel 13, dapat dilihat koefisien korelasi Spearman's rank $\left(\mathrm{r}_{\mathrm{s}}\right)$ adalah sebesar 0.504. Hasil uji signifikansi diperoleh nilai $t$ hitung sebesar 5.668 dan nilai $t$ tabel dengan $\alpha=5 \%$ dan $d k$ (derajat kebebasan) $=\mathrm{n}-2=99$ adalah sebesar 1.984 maka dapat dilihat bahwa t hitung (5.668) > $t$ tabel (1.984) sehingga Ho ditolak. Dengan demikian dapat disimpulkan bahwa terdapat hubungan yang signifikan antara perilaku guru militer pada tahap formulasi (perumusan informasi) dengan hasil pembelajaran. Koefisien korelasi sebesar 0.495 menunjukkan keeratan hubungan antara perilaku guru militer pada tahap formulasi (perumusan informasi) dengan hasil pembelajaran merupakan hubungan yang cukup berarti.

Untuk mengetahui hubungan perilaku guru militer pada tahap koleksi (pengumpulan informasi) dengan hasil pembelajaran, peneliti menggunakan analisis data dengan koefisien korelasi Spearman's rank $\left(\mathrm{r}_{\mathrm{s}}\right)$. Hasil perhitungan dapat dilihat pada tabel berikut. 


\section{Tabel 14}

Hubungan perilaku guru militer pada tahap koleksi (pengumpulan informasi) dengan hasil pembelajaran

\begin{tabular}{llllll}
\hline Variabel & $\mathbf{r}_{\mathbf{s}}$ & $\mathbf{t}_{\text {hitung }}$ & $\mathbf{t}_{\text {tabel }}$ & Keputusan \\
\hline $\begin{array}{l}\text { Perilaku guru } \\
\text { militer pada }\end{array}$ & & & & \\
tahap koleksi & & & & \\
(pengumpulan & 0.477 & 5.699 & 1.984 & Ho ditolak \\
$\begin{array}{l}\text { informasi) } \\
\text { dengan hasil }\end{array}$ & & & & \\
pembelajaran & & & & \\
\hline
\end{tabular}

Sumber: Pengolahan data 2017

Berdasarkan tabel 14, dapat dilihat koefisien korelasi Spearman's rank $\left(\mathrm{r}_{\mathrm{s}}\right)$ adalah sebesar 0.474 . Hasil uji signifikansi diperoleh nilai $\mathrm{t}$ hitung sebesar 5.699 dan nilai $t$ tabel dengan $a=5 \%$ dan $\mathrm{dk}$ (derajat kebebasan) $=\mathrm{n}-2=99$ adalah sebesar 1.984 maka dapat dilihat bahwa t hitung (5.699) > $\mathrm{t}$ tabel (1.984) sehingga Ho ditolak. Dengan demikian dapat disimpulkan bahwa terdapat hubungan yang signifikan antara perilaku guru militer pada tahap koleksi (pengumpulan informasi) dengan hasil pembelajaran. Koefisien korelasi sebesar 0.477 menunjukkan keeratan hubungan antara perilaku guru militer pada tahap koleksi (pengumpulan informasi) dengan hasil pembelajaran merupakan hubungan yang cukup berarti.

Untuk mengetahui hubungan perilaku guru militer pada tahap presentasi (penyajian informasi) dengan hasil pembelajaran, peneliti menggunakan analisis data dengan koefisien korelasi Spearman's rank $\left(\mathrm{r}_{\mathrm{s}}\right)$. Hasil perhitungan dapat dilihat pada tabel berikut.
Tabel 15

Hubungan perilaku guru militer pada tahap presentasi (penyajian informasi) dengan hasil pembelajaran

\begin{tabular}{lllll} 
Variabel & $\mathbf{r}_{\mathbf{s}}$ & $\mathbf{t}_{\text {hitung }}$ & $\mathbf{t}_{\text {tabel }}$ & Keputusan \\
\hline $\begin{array}{l}\text { Perilaku guru } \\
\text { militer pada }\end{array}$ & & & & \\
tahap & & & & \\
$\begin{array}{l}\text { presentasi } \\
\text { (penyajian }\end{array}$ & 0.616 & 7.781 & 1.984 & Ho ditolak \\
$\begin{array}{l}\text { informasi) } \\
\text { dengan hasil }\end{array}$ & & & & \\
pembelajaran & & & & \\
\hline
\end{tabular}

Sumber: Pengolahan data 2017

Berdasarkan tabel 15, dapat dilihat koefisien korelasi Spearman's rank $\left(\mathrm{r}_{\mathrm{s}}\right)$ adalah sebesar 0.618. Hasil uji signifikansi diperoleh nilai t hitung sebesar 7.781 dan nilai $\mathrm{t}$ tabel dengan $\mathrm{a}=5 \%$ dan $\mathrm{dk}$ $($ derajat kebebasan $)=n-2=99$ adalah sebesar 1.984 maka dapat dilihat bahwa $\mathrm{t}$ hitung (7.781) $>\mathrm{t}$ tabel (1.984) sehingga Ho ditolak. Dengan demikian dapat disimpulkan bahwa terdapat hubungan yang signifikan antara perilaku guru militer pada tahap presentasi (penyajian informasi) dengan hasil pembelajaran. Koefisien korelasi sebesar 0.616 menunjukkan keeratan hubungan antara perilaku guru militer pada tahap presentasi (penyajian informasi) dengan hasil pembelajaran merupakan hubungan yang cukup berarti.

\section{SIMPULAN}

Dari hasil dari penelitian yang telah dikemukakan, maka dapat disimpulkan bahwa terdapat hubungan yang positif antara perilaku pencarian informasi dengan hasil pembelajaran. Hasil dari perhitungan Koefisien korelasi menunjukkan ada keeratan hubungan antara perilaku pencarian informasi dengan hasil pembelajaran merupakan hubungan yang cukup berarti. Artinya ada 
perilaku ketika seseorang membutuhkan informasi yang dibutuhkan.

Untuk perilaku guru militer pada tahap inisiasi (awal pencarian informasi) dengan hasil pembelajaran, terdapat hubungan yang signifikan. Hasil dari perhitungan koefisien korelasi menunjukkan keeratan hubungan antara perilaku guru militer pada tahap inisiasi (awal pencarian informasi) dengan hasil pembelajaran merupakan hubungan rendah tapi pasti.

Perilaku guru militer pada tahap seleksi (pemilihan informasi) dengan hasil pembelajaran memiliki hubungan yang signifikan. Hasil dari perhitungan koefisien korelasi menunjukkan keeratan hubungan antara perilaku guru militer pada tahap seleksi (pemilihan informasi) dengan hasil pembelajaran merupakan hubungan yang cukup berarti.

Selanjutnya, terdapat hubungan yang signifikan antara perilaku guru militer pada tahap eksplorasi (penelusuran informasi) dengan hasil pembelajaran. Hasil dari perhitungan koefisien korelasi menunjukkan keeratan hubungan antara perilaku guru militer pada tahap eksplorasi (penelusuran informasi) dengan hasil pembelajaran merupakan hubungan yang cukup berarti.

Dari hasil perilaku guru militer pada tahap formulasi (perumusan informasi) dengan hasil pembelajaran terdapat hubungan yang signifikan. Hasil dari perhitungan koefisien korelasi menunjukkan keeratan hubungan antara perilaku guru militer pada tahap formulasi (perumusan informasi) dengan hasil pembelajaran merupakan hubungan yang cukup berarti.

Antara perilaku guru militer pada tahap koleksi (pengumpulan informasi) dengan hasil pembelajaran terdapat hubungan yang signifikan. Hasil dari perhitungan koefisien korelasi menunjukkan keeratan hubungan antara perilaku guru militer pada tahap koleksi (pengumpulan informasi) dengan hasil pembelajaran merupakan hubungan yang cukup berarti.

Simpulan yang terakhir, yaitu adanya hubungan yang signifikan antara perilaku guru militer pada tahap presentasi (penyajian informasi) dengan hasil pembelajaran. Hasil dari perhitungan koefisien korelasi menunjukkan keeratan hubungan antara perilaku guru militer pada tahap presentasi (penyajian informasi) dengan hasil pembelajaran merupakan hubungan yang cukup berarti.

\section{DAFTAR PUSTAKA}

Fraenkel, J., \& Wallen, N. (2008). How to design and evaluate research in education. New York: McGraw-Hill Higher Education

Gelinas, U. J., \& Dull, R. B. (2012). Accounting information system (9th ed.). United States of America: Thomson

Gumilar, R. A., Winoto, Y., \& Anwar, R. K. (2016). Perilaku pencarian informasi di kalangan para pengrajin golok. Jurnal Kajian Informasi \& Perpustakaan, 4(1), 1-10 Hamami, T., Sinaga, D., \& Erwina, W. (2014). Perilaku pencarian informasi sebagai sumber gagasan pembuatan berita oleh wartawan pikiran rakyat. Jurnal Kajian Informasi $\mathcal{E}$ Perpustakaan, 2(2), 111-120

Rakhmat, J. (2009). Metode penelitian komunikasi. Bandung: PT Remaja Rosdakarya.

Rostina, L. (2006). Perilaku pencarian informasi tenaga kesehatan: Studi kasus tentang perilaku penemuan informasi.

Romney, M. B., \& Steinbart, P. J. (2015). Sistem informasi akuntansi (ed. 13). (Kikin Sakinah, Nur Safira \& Novita Puspasari, penerjemah). Jakarta: Salemba Empat.

Siegel, S. (1992). Statistik nonparametrik untuk ilmu-ilmu sosial. Jakarta: Gramedia 
Sugiyono. (2015). Metode penelitian pendidikan (pendekatan kuantitatif, kualitatif dan RED). Bandung: Penerbit CV. Alfabeta
Sulistiyo-Basuki. (2004). Pengantar dokumentasi. Bandung: Rekayasa Sains Wilson, T. D. (1999). Models in information behaviour research. Journal of Documentation, 55(3), 249-270 